\title{
ULBP2 wt Allele
}

National Cancer Institute

\section{Source}

National Cancer Institute. ULBP2 wt Allele. NCI Thesaurus. Code C105584.

Human ULBP2 wild-type allele is located in the vicinity of $6 \mathrm{q} 25$ and is approximately $7 \mathrm{~kb}$ in length. This allele, which encodes NKG2D ligand 2 protein, is involved in the activation of multiple signaling pathways in primary NK cells. 